УДК 371.11:373.2

DOI: 10.37026/2520-6427-2021-108-4-141-145

\section{Ірина МОСЯКОВА,}

кандидат педагогічних наук, докторант кафедри дошкільної освіти та соиіальної роботи

Мелітопольського держсавного педагогічного університету імені Богдана Хмельнищького, заслужений працівник освіти України, м. Мелітополь, Украӥна ORCID: 0000-0003-4110-5629

e-mail:mosyakova@ukr.net

\title{
МЕНЕДЖМЕНТ У БАГАТОПРОФІЛЬНИХ ЗАКЛАДАХ ПОЗАШКІЛЬНОЇ ОСВІТИ: ПИТАННЯ СИСТЕМНОСТІ УПРАВЛІНСЬКОЇ ДІЯЛЬНОСТІ КЕРІВНИКА
}

\begin{abstract}
Анотація. У статті порушено питання системної структури управлінської діяльності керівника багатопрофільного закладу позашкільної освіти, а також його управлінської і педагогічної діяльності в сучасних умовах. Висвітлено прочеси взаємодї керівника із творчим колективом педагогів. Акцентовано увагу на важливості діалогу для практичної реалізації освітніх послуг. Запропоновано розглядати управління з погляду системності, стратегічності, інновачійності, креативності. Визначено необхідність створення для освітнього менеджменту теоретико-методичної основи, здатної увібрати в себе нові знання та крамі управлінські практики.

На основі аналізу теоретичних джерел, досвіду практичної роботи з'ясовано багатовимірність поняття «управлінська діяльність», окреслено основний підхід до розуміння управлінської діяльності керівника, виокремлено актуалізовану мету й завдання, сутність і принципи управлінської діяльності керівника багатопрофільного закладу позашкільної освіти. Розглянуто
\end{abstract}

питання якості позашкільної освіти як синтетичної категорії, наголошено, що якість освітніх послуг пов'язана не лише із задоволенням культурних потреб вихованиів, набуттям нових навичок у иіккавій для них сфері, а й зі спілкуванням із педагогами і тими референтними групами, чий вибір занять у позашкільний час є близьким для них тощчо.

Схарактеризовано основні вимоги до професійних та особистісних якостей керівника, виокремлено сутність трьох типів керівників («знає - вміє», «знає - частково вміє», "уміє - частково знає»), щьо представлені в науково-методичній літературі.

Доведено, щзо багатопрофільні заклади позашкільної освіти передусім мають орієнтуватися на ефективність власної організаиіі, успішність та оптимальну продуктивність у наданні освітніх послуг.

Ключові слова: менеджмент, позашкільна освіта, управлінська компетентність, багатопрофільний заклад позашкільної освіти.

\author{
Iryna MOSYAKOVA, \\ Candidate of Pedagogical Sciences, \\ Honored Worker of Education of Ukraine, \\ Doctoral student of the Department \\ of Preschool Education and Social Work, \\ Bohdan Khmelnytsky Melitopol \\ State Pedagogical University, \\ Melitopol, Ukraine \\ ORCID: 0000-0003-4110-5629 \\ e-mail:mosyakova@ukr.net
}

\section{MANAGEMENT IN MULTIDISCIPLINARY INSTITUTIONS OF EXTRACURRICULAR EDUCATION: QUESTIONS OF SYSTEM OF MANAGERIAL ACTIVITY OF THE HEAD}

Abstract. In this article the questions of system structure of administrative activity are investigated, the questions of administrative and pedagogical activity of the head of multidisciplinary establishment of out-ofschool education in modern conditions are considered. The author reveals the processes of interaction of the head with the creative team of teachers, draws attention to the need for dialogue, which is important for the practical implementation of educational services. The author proposes to consider management from the point of view of systemic, strategic, innovative, creative, proves the need to build a theoretical and methodological basis for education management as a special platform that can absorb new knowledge and best management practices. 
Based on the analysis of theoretical sources, practical experience it has been clarified main approaches to understanding the managerial activity of the head, multidimensionality of the concept of "management activity», actualized purposes and tasks, essence and principles of management activity.

The article highlights the position of the quality of extracurricular education. Which is a synthetic category and emphasizes that the quality of educational services is associated with the satisfaction of students with cultural lifestyles, acquired new skills in the field they are interested in, leisure in general, communication with teachers and those reference groups that are close in choosing leisure activities.

The basic requirements to professional and personal qualities of the head are characterized, the existence in scientific literature of three types of heads is emphasized («knows - is able», «knows - partially is able», «is ablepartially knows»).

The author deliberately avoids issues related to competitiveness and argues that multidisciplinary extracurricular education institutions should focus on the efficiency of their own organization, success and optimal productivity in providing educational services.

Key words: management, extracurricular education, managerial competence, multidisciplinary institution of extracurricular education.

Постановка проблеми. У сучасних умовах реформування системи позашкільної освіти важливу роль відіграє управлінська компетентність керівника позашкільного закладу, який нині потребує нових знань щодо управління освітнім процесом, нових підходів, що враховують як вітчизняні, так і міжнародні тенденції розвитку управлінських практик. Зауважимо, що в сучасних умовах розвитку автономії попередні моделі управління педагогічним процесом у багатопрофільних закладах позашкільної освіти, на жаль, уже застаріли. Так, у минулому керівники закладів позашкільної освіти за підтримки місцевих адміністрацій намагалися створювати творчі об'єднання дітей та учнівської молоді за вимогою представників органів місцевого самоврядування та органів управління освітою, що не завжди задовольняло інтереси широких верств населення, зокрема й самих вихованців.

Глобальні зрушення, що відбуваються нині у сфері освіти, спонукають керівників до пошуку нових напрямів управління багатопрофільними закладами позашкільної освіти, враховуючи можливості потенціалу позашкільної (неформальної) освіти й належним чином реалізовуючи його.

Аналіз наукових досліджень і публікацій. Реалізація практичної діяльності керівника багатопрофільного закладу позашкільної освіти передбачає дослідження низки питань, що пов'язані з управлінською діяльністю, зокрема: сутності та особливостей управлінсько-педагогічної діяльності (В. Демчук, 2007; О. Доброзорова, І. Осадчук, 2009; 3. Ковальчук, 2013 та ін.); цілеспрямованості в роботі керівників закладів освіти (В. Куценко, 2012; О. Шикула, Б. Мицак, 2012 та ін.), якості освітніх послуг (Г. Кільова, 2012) та ін. Досвід управлінської діяльності в багатопрофільному закладі позашкільної освіти у поєднанні з творчими доробками українських і зарубіжних учених дає змогу визначити ті позитивні здобутки, що відзначаються актуальністю для сфери управління в сучасних умовах.

Мета статті - окреслити особливості менеджменту в багатопрофільних закладах позашкільної освіти, зокрема розширити уявлення про його вплив на управлінсько-педагогічну діяльність.

Виклад основного матеріалу дослідження. Керівник багатопрофільного закладу позашкільної освіти - це не просто менеджер. У своїй роботі він поєднує два види діяльності - педагогічну й управлінську. Саме тому виконання ним професійних завдань - справа не 3 легких, оскільки необхідно не лише знати всі тонкощі педагогічної діяльності, а й уміти керувати творчим колективом педагогів. Актуальною в цьому контексті вважаємо думку 3. Ковальчук, яка вбачає призначення управлінської педагогічної діяльності у створенні такого освітнього середовища, що «...ефективно функціонує та відповідає сучасним вимогам, $є$ привабливим для реального та потенційного споживача освітніх послуг, вчасно реагує на нові технології і методи педагогічної діяльності та їх впровадження» (Ковальчук, 2013, c. 296).

Під впливом освітніх реформ, що відбуваються впродовж останнього часу в галузі освіти та мають істотний вплив як на педагогічну професію, так і на систему управління колективом педагогів, змінюється сутність позашкільної освіти. Ці зміни передусім зумовлені бурхливим технічним прогресом, збільшенням кількості сайтів із навчальними матеріалами (відео та аудіо) тощо. Сьогоднішні вихованці, крім спілкування $з$ педагогами, можуть самостійно набувати нових знань, умінь і навичок, що є складовими життєво важливих компетентностей, змістовно проводити дозвілля, навчаючись новому.

Основне завдання сучасного керівника - під впливом реформаторських змін в освіті розвивати здатність до реальної оцінки життєво важливих ситуацій, що складаються в закладі позашкільної освіти, враховувати власні можливості та безпосередньо використовувати їх в управлінні багатопрофільним закладом позашкільної освіти. Сутність такої діяльності трактують як синтез професіоналізму, творчості, високого рівня професійної культури тощо. Аналізуючи менеджмент в освіті як вид діяльності, В. Куценко зауважує, що така діяльність має бути спрямована «...на досягнення певних окреслених цілей виробничо-господарської організації (підприємства), що функціонує в ринкових умовах, шляхом ефективного використання матеріальних, людських і фінансових ресурсів», а також передбачає «... вміння спілкуватися, організовувати ефективну роботу персоналу загалом і управлінського зокрема, досягати поставленої мети, використовуючи працю, інтелект, мотиви поведінки інших людей» (Куценко, 2012 , c. 274).

Актуалізуємо увагу на тому, що сьогодні, в період переоцінки ролі педагогічної праці, керівник закладу позашкільної освіти повинен не лише застосовувати набуті інноваційні знання, а й брати на себе відповідальність за впровадження більш ефективної структури управлінської педагогічної діяльності. На нашу думку, 
така структура має насамперед охоплювати: мету і завдання управлінської діяльності у сфері позашкільної освіти; принципи управлінської діяльності; основні закономірності діяльності керівника в роботі 3 педагогічним колективом; концептуальні положення щодо зростання професіоналізму керівника, методи управлінської діяльності та ін. Також важливими є питання щодо підвищення культури автономізації педагогів, посилення контролю за якістю надання освітніх послуг, удосконалення особистих якостей педагогів (авторитетність, наполегливість, енергійність, доброзичливість, ініціативність, обережність, евристичність тощо).

Метою роботи керівника багатопрофільного закладу позашкільної освіти є забезпечення успішності роботи закладу, максимальної ефективної діяльності кожного педагога зі здобувачами позашкільної освіти, що грунтується на позиціях цілеспрямованості, системності, єдності, творчості, привабливості. Актуальною у зв'язку з цим $є$ думка О. Шикули та Б. Мищак щодо визначення мети діяльності керівника закладу: «Менеджер «створений» із зовсім інших «матеріалів», i його призначення має іншу мету. Він має справу не зі своїм власним світом, а зі світом інших людей - саме приналежність реальності значній кількості суб'єктів позбавляє його права нав'язувати цій реальності будьякий ідеал. Неможливо впровадити нову технологію у виробництво чи змусити підлеглих робити те, що потрібно, вірячи в існування світової гармонії» (Шикула, Мищак, 2012, с. 196).

Основні завдання, які виконує керівник багатопрофільного закладу позашкільної освіти, пов'язані зі сферою ухвалення рішень і їхньою обов'язковою реалізацією, що передбачає створення умов для імплементації ухвалених рішень, підвищення ефективності управління тощо. Соціальна реальність, з якою постійно стикається керівник, змушує його діяти, зважаючи на традиційні підходи та нові перспективи у прийнятті рішень, що мають не тільки переваги, а й застереження. Неправильні рішення можуть непоправно зашкодити роботі закладу, а отже, доцільно зважати на переваги й застереження, враховувати наявні складні ситуації, що можуть вплинути на ухвалення рішень.

Керівник багатопрофільного закладу позашкільної освіти для успішного виконання завдань повинен мати чітке розуміння сутності та змісту управлінської діяльності. Таке розуміння сприяє злагодженій роботі закладу освіти, його подальшому розвитку й удосконаленню механізмів функціонування, розширенню ділових відносин із територіальними громадами, представниками батьківської спільноти, а також колегами й самими здобувачами позашкільної освіти. Звертаємо увагу на те, що під поняттям «управління» сьогодні варто розуміти таку діяльність, що спрямована на організацію, ухвалення рішень, контроль за їхнім виконанням, аналіз останніх тенденцій і поточних ситуацій тощо. Л. Шипиліна визначає управлінську діяльність як такий «...вид діяльності людини, що змінюється в їі структурі відповідно до оформлення у свідомій діяльності людини стосовно виробництва необхідних людських благ. Особливістю цього виду діяльності є передбачення, самоорганізація, контроль за плануванням дій тощо» (Шипилина, 2017, с. 11). Зі свого боку О. Доброзорова та I. Осадчук уважають таку діяльність особливим різновидом свідомої доцільної діяльності людини, в якій «...відображається реальна взаємодія об'єктивних і суб' єктивних факторів суспільної діяльності, спрямованої на ефективне функціонування робіт, що здійснюються індивідуально або колективно». Тобто, доцільність управлінської діяльності автори вбачають «...у намаганні досягти тих чи інших цілей, а також у вирішенні певних завдань та виконанні відповідних функцій» (Доброзорова, Осадчук, 2009, с. 12).

3 огляду на ту діяльність, яку здійснює керівник багатопрофільного закладу позашкільної освіти, варто детально розглянути основні методи управління, що за своєю сутністю і спрямуванням є важливими інструментами для досягнення результатів роботи закладу, зокрема щодо надання якісних освітніх послуг. Зауважимо, що якість освіти - це ключовий момент у роботі керівника. На думку Г. Кільової, «...якість освіти є синтетичною категорією, що відображає всі компоненти й аспекти розвитку освіти як системи» (Кільова, 2012, с. 23).

На наше переконання, якість отриманих вихованцями закладів позашкільної освіти різноманітних освітніх послуг передусім пов'язана із задоволенням їхніх освітніх і культурних потреб, набуттям нових знань, умінь і навичок у цікавій дозвіллєвій діяльності, зі спілкуванням із педагогами і тими групами вихованців (слухачів), чий вибір занять у час, вільний від навчання в закладі загальної середньої освіти, $\epsilon$ привабливим для них. Зважаючи на це, практичні дії управління мають передбачати аналіз останніх тенденцій у роботі закладів позашкільної освіти, оцінку організаційно-педагогічних умов і педагогічних ситуацій, розгортання культурно-освітнього простору. Чим глибшим $є$ пізнання практичних управлінських дій керівником, тим обгрунтованішим буде вибір ним необхідних методів управління, до яких належать: науковий метод (спостереження, формулювання гіпотез, верифікація); методи збору, обробки й аналізу інформації щодо функціонування та розвитку багатопрофільного закладу позашкільної освіти; методи моделювання, проєктування робочих завдань, налагодження міжособистісних відносин, планування; метод управління за цілями; метод розподілу ресурсів (часових, людських, матеріальних); методи контролю, регулювання, координації, прогнозування; метод експертних оцінок; ситуаційний метод; метод мотивації та ін. Отже, знання про методи управління в багатопрофільних закладах позашкільної освіти допоможуть керівникові урізноманітнити та розширити його можливості щодо реалізації практичних дій, які мають бути спрямовані на досягнення відповідних цілей і виконання завдань, що постають перед педагогічним колективом закладу.

Управління педагогічними працівниками має відображати бачення стратегії діяльності закладу позашкільної освіти та певною мірою бути адаптованим до процесу надання освітніх послуг. Це допоможе керівникам відповідати на ті виклики, що зазвичай постають перед суспільством, а отже, і перед закладами позашкільної освіти. Водночас важливо використовувати позитивну мотивацію, знижувати бюрократичні 
процедури контролю, вирішувати різні питання освітньої діяльності шляхом діалогу.

Таким чином, можемо констатувати, що управління - це особливий підхід до стратегічного розгортання діяльності педагогічних працівників і фахівців закладу, які використовують інноваційні освітньо-виховні, розвивальні та соціалізуючі техніки і технології особистісного зростання й розвитку вихованців. Ми свідомо уникаємо такого питання, як «конкурентні переваги закладу», адже багатопрофільні заклади позашкільної освіти передусім повинні орієнтуватися на ефективність власної організації, успішність та оптимальну продуктивність у наданні освітніх послуг. Саме це сприятиме орієнтації на високу якість подібних послуг, адже вони необхідні для задоволення культурних потреб не лише вихованців та їхніх батьків, а й суспільства в цілому.

Зважаючи на викладене вище, зазначимо, що управління багатопрофільним закладом позашкільної освіти - процес творчий. У науково-методичній літературі представлено й схарактеризовано такі основні типи керівників закладів освіти: перший тип - керівник-організатор («знає - уміє»), він є найціннішим, адже у процесі управління знає та вміє використовувати різні методи і засоби управління діяльністю закладу освіти; другий тип - керівник, який має грунтовну теоретичну підготовку, але в нього недостатньо управлінського досвіду («знає - частково вміє»); третій mun - керівник-практик («уміє - частково знає»), який загалом знає, як використовувати методи управління, але має недостатню теоретичну підготовку (Ковтун, 2012 , с. 90). Отже, варто закцентувати увагу на необхідності підвищення кваліфікаційних характеристик керівників, які здійснюють процес управління творчими колективами в закладах позашкільної освіти.

Підвищення кваліфікаційних характеристик відбувається у разі набуття керівниками інноваційних знань, умінь і навичок в управлінні, удосконаленні власної педагогічної майстерності. У зв'язку з цим можемо зробити висновок, що нові знання, вміння, навички, досвід у галузі позашкільної освіти підвищують якість освітньої діяльності, а це, як відомо, сприяє ефективному набуттю вихованцями життєво важливих компетентностей.

Керівникам багатопрофільних закладів позашкільної освіти, без сумніву, важко розпланувати свою діяльність на декілька років уперед, але творчі якості та прагнення до постійного вдосконалення та навчання впродовж життя, вміння чинити етично, толерантно в розмаїтому й відкритому суспільстві будуть необхідними завжди.

Сьогодні актуальними є дослідження, в яких аналізується креативна освіта менеджерів. Так, I. Саух вказує на те, що «...креативна освіта, хоч і перебуває на початковому етапі розвитку, однак має неабиякі перспективи, мотивує до самостійного осмислення дійсності, самопізнання індивідуальності, перетворення знань на потенціал мислення та саморозвитку. Вона $\epsilon$ альтернативою освіті репродуктивній, прагматичній і нормативній, освіті «знання досвіду». Креативна освіта виводить освіту менеджера на рівень управління знаннями, трансформуючи їх у комплекс важливих, позитивних характеристик професійного формування та становлення менеджера, створює умови для вияву креативності особистості та стає безпосереднім джерелом креативних управлінських інновацій» (Саух, 2019 , с. 84)

Керівники в галузі позашкільної освіти покликані розробляти нові стратегії управління, спрямовані на підвищення мотивації педагогів, зміцнення їхнього потенціалу в процесі надання освітніх послуг, поліпшення процесів міжособистісного та ділового спілкування тощо. Нове бачення додаткових освітніх послуг та планування в системі управління багатопрофільними закладами позашкільної освіти спрямовані на трансформацію позашкілля, забезпечення продуктивності майбутньої професійної діяльності кожного вихованця. Зважаючи на це, нові стратегії управління багатопрофільними закладами позашкільної освіти неабияк необхідні та мають випереджати час.

Саме тому вважаємо за доцільне наголосити на самореалізації як одній із форм професійного самоствердження, що стає можливою завдяки реалізації власних творчих сил керівника закладу позашкільної освіти, тобто успішність процесів самореалізації керівника має враховувати не тільки різні стилі управління, а й можливість одночасно вибудовувати власний інноваційний стиль, що поєднує знання та особистий досвід, а також позитивний досвід колег-керівників.

Здатність до управління не належить до вроджених здатностей, вона розвивається шляхом здобуття нових знань, набуття досвіду управління іншими людьми, наслідування успішного досвіду управління закладами освіти, засвоєнням правил, норм і вимог, що є дієвими в практиці управління багатопрофільними закладами позашкільної освіти. Відповідно управління як особистісний феномен діяльності керівника передбачає наявність у нього таких особистісних рис, як ініціативність, самостійність, автономія, оригінальність, креативність, лідерство тощо. Спрямування на успішність в управлінні має на меті виконання новаторської та суспільно значущої діяльності, спрямованої на розвиток як педагогічного колективу загалом, так i можливостей кожного педагога зокрема, що прагнуть до самовдосконалення й особистого творчого розкриття у процесі застосування оригінальних педагогічних практик.

У цьому контексті актуальним $є$ вивчення досвіду управління мистецькими колективами, які для створення певного артпродукту мають працювати спільно, злагоджено, постійно підвищуючи свою майстерність. Саме тому для розвитку можливостей педагогів потрібно створити відповідні умови для їхньої самореалізації, індивідуальності, креативності. Також важливими якостями керівника багатопрофільного закладу позашкільної освіти, на нашу думку, $є$ енергійність, емоційність, активність, вимогливість, критичність, гуманізм, уміння так вибудувати систему взаємин у колективі, щоб кожен педагог відчував себе важливою складовою злагодженого колективу, причетним до розвитку суспільства, утвердження загальнолюдських цінностей, збереження нематеріальної культурної спадщини.

Висновки. Узагальнюючи викладене вище, можемо констатувати системність і складність освітнього 
менеджменту в багатопрофільних закладах позашкільної освіти, що має на меті забезпечення ефективності та якості надання освітніх послуг як для здобувачів позашкільної освіти, так і їхніх батьків. У зв'язку з цим діяльність керівників закладів освіти повинна спиратися на чітко вибудувану теоретико-методичну основу, орієнтуватися на нові знання й успішні практики в галузі управління педагогічним колективом закладу позашкільної освіти, враховуючи новітні вітчизняні та зарубіжні тенденції додаткової (неформальної) освіти.

Перспективу подальших досліджень у даному напрямі вбачаємо у вивченні особливостей управлінської педагогічної діяльності керівників закладів позашкільної освіти у межах неформальної освіти.

\section{СПИСОК ВИКОРИСТАНОЇ ЛІТЕРАТУРИ}

Демчук, В. (2007). Основи освітнього менеджменту. Київ: Ленвіт. 263 с.

Ковальчук, 3. (2013). Управлінська педагогічна діяльність як психолого-педагогічна система. Науковий вісник Львівського державного університету внутрішніх справ. Серія психологічна. № 1. С. 295-304.

Куценко, В. (2012). Менеджмент освіти: його місце і роль у забезпеченні конкурентоздатності економіки. Економіка. Управління. Інновації. Серія «Економічні науки». № 1. URL: http://nbuv.gov.ua/UJRN/ eui_2012_1_27 (дата звернення: 17.07.2021).

Шикула, О., Мицак, Б. (2012). Управлінська діяльність та виклики організаційної культури сучасності. Наукові записки Львівського університету бізнесу mа права. Вип. 8. С. 193-196. URL: http://nbuv.gov.ua/ UJRN/Nzlubp_2012_8_45 (дата звернення: 17.07.2021).

Шипилина, Л. (2017). Менеджмент в образовании. 2-е изд., перераб. и доп. Омск: Изд-во ОмГПУ. 312 с.

Доброзорова, О., Осадчук, I. (2009). Організація праці менеджера. Київ: Кондор. 452 с.

Кільова, Г. (2012). Якість освіти як ключова категорія менеджменту освіти. Освіта та педагогічна наука. № 5-6. С. 22-26. URL: http://nbuv.gov.ua/UJRN/ OsDon_2012_5-6_5 (дата звернення: 17.07.2021).

Ковтун, Р. (2018). Управленческая культура руководителя творческого коллектива. Образовательный менеджмент: теория и практика / под ред. 3. М. Большаковой. Челябинск: Цицеро. С. 89-106.

Cayx, I. (2019). Проблеми розвитку креативного менеджменту та креативної освіти в сучасних умовах. Вісник Київського інституту бізнесу та технологій. № 2. С. 81-85. URL: http://nbuv.gov.ua/UJRN/ Vkib_2019_2_21 (дата звернення: 17.07.2021).

\section{REFERENCES}

Demchuk, V. (2007). Osnovi osvitn'ogo menedzhmentu [Foundations of educational management]. Kyiv: Lenvit. 263 s. [in Ukrainian].

Koval'chuk, Z. (2013). Upravlins'ka pedagogichna diyal'nist' yak psihologo-pedagogichna sistema [Management pedagogical activity as a psychological and pedagogical system]. Naukovij Visnik L'vivs 'kogo derzhavnogo universitetu vnutrishnih sprav. Seriya psihologichna. № 1. S. 295-304. [in Ukrainian].

Kucenko, V. (2012). Menedzhment osviti: jogo misce i rol' u zabezpechenni konkurentozdatnosti ekonomiki [Education management: its place and role in ensuring the competitiveness of the economy]. Ekonomika. Upravlinnya. Innovaciï. Seriya «Ekonomichni nauki». № 1. URL: http://nbuv.gov.ua/UJRN/eui_2012_1_27. (data zvernennia: 17.07.2021). [in Ukrainian].

Shikula, O., Micak, B. (2012). Upravlins'ka diyal'nist' ta vikliki organizacijnoï kul'turi suchasnosti [Management activities and challenges of modern organizational culture]. Naukovi zapiski L'vivs'kogo universitetu biznesu ta prava. Vip. 8. S. 193-196. URL: http://nbuv.gov.ua/ UJRN/ Nzlubp_2012_8_45. (data zvernennia: 17.07.2021). [in Ukrainian].

Shipilina, L. (2017). Menedzhment v obrazovanii [Management in education]. 2-e izd., pererab. i dop. Omsk: Izd-vo OmGPU. 312 s. [in Russian].

Dobrozorova, O., Osadchuk, I. (2009). Organizaciya praci menedzhera [Organization of the manager's work]. Kyiv: Kondor. 452 s. [in Ukrainian].

Kil'ova, G. (2012). Yakist' osviti yak klyuchova kategoriya menedzhmentu osviti [Quality of education as a key category of education management]. Osvita ta pedagogichna nauka. № 5-6. S. 22-26. URL: http://nbuv.gov.ua/ UJRN/OsDon_2012_5-6_5. (data zvernennia: 17.07.2021). [in Ukrainian].

Kovtun, R. (2018). Upravlencheskaya kultura rukovoditelya tvorcheskogo kollektiva [Managerial culture of the creative team leader]. Obrazovatelnyy menedzhment: teoriya i praktika / pod red. Z. M. Bolshakovoy. Chelyabinsk: Tsitsero. S. 89-106. [in Russian].

Sauh, I. (2019). Problemi rozvitku kreativnogo menedzhmentu ta kreativnoïo sviti v suchasnih umovah [Problems of development of creative management and creative education in modern conditions]. Visnik Kï̈vs'kogo institutu biznesu ta tekhnologij. № 2. S. 81-85. URL: http:// nbuv.gov.ua/UJRN/Vkib_2019_2_21. (data zvernennia 17.07.2021). [in Ukrainian].

Дата надходження до редакиії: 03.08.2021 p. 